\title{
Penanaman Nilai-Nilai Religius Dalam Membentuk........ \\ PENANAMAN NILAI-NILAI RELIGIUS DALAM MEMBENTUK AKHLAK \\ KARIMAH BAGI PESERTA DIDIK DI MI AR-RAHIM \\ KECAMATAN ARJASA KABUPATEN JEMBER
}

\author{
Agus Zainudin ${ }^{1}$ \\ (guszain90@gmail.com)
}

\begin{abstract}
The industry of era 4.0 has an impact on competitive advantage to life aspects. In the context of education, being competitive to get the best education in academic achievement has become a kind of competition. This is where the demands and expectations of some users of education emerge to bring about human excellence through the concept of moral in the world of education. Moral character can be formed if humans respect each other and carry out their religious teachings with pure and consistent. Religious values are important values to be instilled to students because these values will be able to make students become more exemplary, tolerant and more religious and even practice their religious teachings and touch their affection and psychomotor.

This scientific article discusses the cultivation of religious values by forming religious culture so that eventually students will get used to practicing religious values and will become learners who respect each other even with other religions and have a moral character.
\end{abstract}

Keywords: religious values, moral, character, students

\begin{abstract}
Abstrak
Era industry 4.0 membawa dampak pada persaingan keunggulan di aspek-aspek kehidupan. Dalam konteks pendidikan, persaingan untuk mendapatkan pendidikan terbaik dalam prestasi akademis telah menjadi semacam kompetisi. Di sinilah muncul tuntutan dan harapan dari beberapa pihak pengguna pendidikan untuk memunculkan keunggulan manusia melalui konsep akhlak karimah di dunia pendidikan. Akhlak karimah dapat dibentuk jika manusia saling menghormati dan menjalankan ajaran agamanya dengan murni dan konsekuen. Nilai religius merupakan nilai penting untuk ditanamkan kepada peserta didik karena nilai tersebut akan mampu menjadikan peserta didik menjadi lebih teladan, toleran dan lebih religius bahkan mengamalkan ajaran agamanya dan menyentuh afeksi dan psikomotoriknya.

Artikel ilmiah ini membahas tentang penanaman nilai religius dengan membentuk budaya religius sehingga pada akhirnya peserta didik akan terbiasa mengamalkan nilai-nilai religius dan akan menjadi peserta didik yang menghormati sesamanya, bahkan dengan yang lain agama serta memilki akhlak karimah.
\end{abstract}

Kata Kunci: nilai-nilai religius, akhlak karimah, siswa

\footnotetext{
${ }^{1}$ Dosen Program Studi Pendidikan Guru Madrasah Ibtidaiyah Fakultas Tarbiyah Universitas Islam Jember
} 


\section{Agus Zainudin}

\section{PENDAHULUAN}

Pada era industri 4.0 kesadaran orangtua akan pentingnya pendidikan yang berkualitas bagi anak-anaknya semakin meningkat, sekolah yang berkualitas semakin dicari. Orang tua tidak peduli apakah sekolah negeri ataupun swasta. Sekolah-sekolah yang bermutu dan bermuatan agama, menjadi pilihan pertama bagi orang tua di berbagai daerah. Orang tua menyadari benar akan pentingnya pendidikan yang bermateri keagamaan bagi anak-anaknya dalam rangka untuk menangkal pengaruh yang negatif di era ini. Meskipun demikian, walaupun terdapat juga orang tua yang menyekolahkan anaknya tanpa memperhatikan aspek keagamaan dan lebih mementingkan mutu sekolah yang bersangkutan.

Kondisi yang terjadi demikian tersebut dikarenakan kurangnya kesadaran orang tua dalam mendidik anaknya, sehingga anaknya akan berkembang sendiri dengan lebih liar dan akan mengakibatkan penyimpangan. Solusi yang biasanya diambil oleh orang tua adalah menyekolahkan anaknya ke pesantren atau menyekolahkan anaknya ke sekolah yang masuk satu hari penuh. Namun, dalam hal ini pesantren nampaknya kalah saing dengan sekolah umum yang berlabel Islam. Salah satu indikator kemenangan persaingan tersebut adalah banyak beridiri MI, SDI dan/ atau sekolah yang berlabel Islam lainnya. Kesadaran orangtua akan pendidikan Islam dan penanaman nilai-nilai Islam bagi anak-anaknya nampaknya sesuai dengan pandangan Jalaluddin. Menurut Jalaluddin yang dikutip oleh Kartika Nur Fathiya, mengatakan bahwa pengenalan ajaran agama sangat berpengaruh dalam pembentukan jiwa anak. Jiwa dan kecerdasan spiritual anak akan lebih terlatih dan terbentuk dengan pembiasaan setiap harinya. ${ }^{2}$

Pada dasarnya kesadaran agama berpengaruh pada bentuk kegiatan-kegiatan dalam kehidupan sehari-hari, seperti: mengucapkan salam, hormat-menghormati, saling menyayangi, saling tolong menolong dengan sesama, menghargai sesama, bersedekah, membantu orang menyeberang dan kegiatan-kegitan baik lainnya. Hal tersebut juga dijelaskan oleh Marzuki, bahwa pada dasarnya tingginya kesadaran agama berpengaruh pada aktualisasi jiwa seseorang dalam kehidupan sehari-hari yang dimanifestasikan dalam

\footnotetext{
${ }^{2}$ Kartika Nur Fathiya, Problem, Dampak, dan Solusi Transformasi Nilai-nilai Agama pada Anak Pra-sekolah (Dinamika Pendidikan No. 1/ Th. XIV / Mei 2007), 102-103
} 
Penanaman Nilai-Nilai Religius Dalam Membentuk........ bentuk kegiatan-kegiatan olah kejiwaan dan olah spiritual seperti saling tolong menolong dengan sesama, menghargai sesama, dan menginternalisasikan nilai-nilai universal. ${ }^{3}$

Penanaman nilai-nilai agama mulai dini merupakan hal yang sangat penting dilakukan dalam suatu lembaga pendidikan karena penanaman nilai-nilai agama terdapat hubungan timbal balik antara pendidik dan peserta didik. Di mana dalam hal ini, pendidik tidak hanya berfungsi sebagai pengajar saja, namun juga sebagai pembimbing dan muaddib atau murabbi bagi peserta didik, yakni sebagai orang yang bertugas membimbing, mengarahkan, menunjukkan serta menginternalisasikan nilai-nilai agama kepada anaknya. ${ }^{4}$ Seorang pendidik bertugas tidak hanya memberikan ilmu (knowledge) kepada peserta didik, tetapi juga mentransformasikan nilai-nilai (value) pada peserta didik. Salah satu komponen yang sangat penting dalam sistem kependidikan adalah pendidik, karena ia yang akan mengantarkan dan membimbing bahkan mengarahkan peserta didik pada tujuan yang telah ditentukan, bersama komponen yang lain terkait dan lebih bersifat komplementatif (pelengkap). ${ }^{5}$

Peserta didik merupakan komponen yang tidak kalah pentingnya dalam proses pembelajaran. Hubungan antara pendidik dan peserta didik dalam proses pembelajaran seperti hubungan orang tua dengan anaknya. Pendidik secara spiritual berkewajiban untuk mendidik peserta didik dan menanamkan nilai-nilai agama kepadanya melalui proses pendidikan dan pembiasaan perilaku di lingkungan sekolah yang kemudian diharapkannya dapat mengamalkan di rumah maupun di masyarakat. Adapaun Nilai-nilai tersebut, seperti: nilai iman, ibadah, akhlak, dan sosial dan lain sebagainya.

\section{PEMBAHASAN}

\section{Konsep Nilai Religius}

Secara bahasa, nilai religius berasal dari gabungan dua kata, yaitu kata nilai dan kata religius. Kata nilai dapat diartikan secara etimologis dan terminologis. Dari segi

\footnotetext{
${ }^{3}$ Marzuki, Pendidikan Agama Islam di Perguruan Tinggi Umum dan Pemberdayaan Masyarakat Indonesia (Cakrawala Pendidikan No. 1 Tahun XVI Februari 1997), 45

${ }^{4}$ Ahmad Tafsir, Ilmu Pendidikan dalam Perspektif Islam (Bandung: Remaja Rosda Karya, 1992), 74-75

${ }^{5}$ Khoiron Rosyadi, Pendidikan Profetik (Yogyakarta: Pustaka Pelajar, 2004), 172
} 


\section{Agus Zainudin}

etimologis, nilai adalah harga, derajat. ${ }^{6}$ Nilai adalah ukuran untuk memilih tindakan atau upaya kegiatan dan tujuan tertentu. ${ }^{7}$ Sedangkan secara terminologis, Muhmidayeli mendefinisikan nilai adalah gambaran tentang sesuatu yang indah dan menarik yang mempesona, menakjubkan, yang membuat kita bahagia, senang dan merupakan sesuatu yang menjadikan seseorang atau sekelompok orang memilikinya. Nilai dapat juga diartikan dalam makna benar-salah, baik-buruk, manfaat atau berguna, indah dan jelek. ${ }^{8}$ Nilai secara umum, sebagaimana yang didefinisikan oleh Hamka dengan standar atau ukuran (norma) yang digunakan untuk mengukur segala sesuatu. ${ }^{9}$

Kamus Besar Bahasa Indonesia mengartikan nilai adalah sesuatu yang menyempurnakan manusia sesuai dengan hakikatnya, seperti: etika, sikap dan lain-lain. ${ }^{10}$ Alport sebagaimana yang dikutip oleh Mulyana, mengemukakan bahwa nilai adalah keyakinan yang membuat seseorang berperilaku atas dasar pilihannya atau dalam kata lain keyakinan sebagai dasar pilihan tindakan. ${ }^{11}$ Selain itu, kebenaran sebuah nilai pada dasarnya tidak menuntut adanya pembuktian empiris, namun lebih terkait dengan pemahaman, kesadaran, trust dan apa yang dikehendaki atau tidak dikehendaki, disenangi atau tidak disenangi oleh seseorang. Jadi pada intinya nilai merupakan suatu keyakinan sebagai dasar pilihan tindakan yang menjadikan hidupnya pada masa yang akan datang mempunyai makna atau tidak, serta yang akan menjadi bahan pemikirannya untuk mencapai tujuannya.

Kata religius biasa diartikan dengan kata agama, namun juga bisa diartikan sebagai keberagamaan. Agama, menurut Harun Nasution dalam pendapatnya yang dikutip oleh Abuddin Nata, tersusun dari dua kata, a = tidak dan gama = pergi, jadi agama artinya tidak pergi, tetap di tempat, diwarisi secara turun temurun. ${ }^{12}$ Agama secara istilah menurut Frazer sebagaimana dikutip Nuruddin adalah sistem kepercayaan yang tidak stagnan dan

\footnotetext{
${ }^{6}$ JS Badudu dan Sutan Muhammad Zain, Kamus Umum Bahasa Indonesia (Jakarta: Pustaka Sinar Harapan, 1996), 944

${ }^{7}$ Khoiron Rosyadi, Pendidikan Profetik, cet. 1 (Yogyakarta: Pustaka Pelajar, 2004), 114

${ }^{8}$ Muhmidayeli, Filsafat Pendidikan (Bandung: Refika Aditama, 2013), 101

${ }^{9}$ Abd. Haris, Etika Hamka (Yogyakarta: LKiS, 2012), 30

${ }^{10}$ Kemdikbud, "https://kbbi.kemdikbud.go.id/entri/nilai" (diakses pada Tanggal 01 April 2020 Pukul 13.26 WIB)

${ }^{11}$ Rohmat Mulyana, Mengartikulasikan Pendidikan Nilai (Bandung: Alfabeta, 2004), 9

12 Abuddin Nata, Metodologi Studi Islam (Jakarta: Raja Grafindo Persada, 2003), 9
} 
Penanaman Nilai-Nilai Religius Dalam Membentuk

berkembang sesuai dengan tingkat kognisi seseorang. ${ }^{13}$ Clifford Geertz mengemukakan sebagaimana dikutip Roibin, agama dan spirit itu beda sedangkan spirit adalah semangat, pada dasarnya telah terjadi hubungan yang akrab antara agama sebagai sumber nilai dan agama sebagai sumber kognitif atau pengetahuan. Pertama, agama merupakan dasar bagi tindakan manusia (pattern for behaviour). Sebagai dasar tindakan agama menjadi arah bagi tindakan manusia. Kedua, agama merupakan pola dari tindakan manusia (pattern of behaviour). Sebagai pola ini agama dianggap sebagai hasil dari cipta, rasa dan karsa manusia yang tidak jarang telah dipengaruhi oleh kekuatan mistis. ${ }^{14}$

Agama dalam perspektif yang kedua ini sering dipahami sebagai bagian dari sistem kebudayaan, ${ }^{15}$ yang tingkat efektifitas fungsi ajarannya kadang tidak kalah dengan agama formal. Namun, agama merupakan sumber nilai yang tetap harus dipertahankan aspek otentikannya. Jadi di satu sisi, agama dipahami sebagai hasil menghasilkan dan berinteraksi dengan budaya. Pada sisi lain, agama juga tampil sebagai sistem nilai yang mengarahkan bagaimana manusia berperilaku. Jadi agama adalah ajaran yang berasal dari Tuhan atau renungan manusia yang terkandung dalam kitab suci yang turun temurun diwariskan oleh suatu generasi ke generasi berikutnya dengan tujuan untuk memberi tuntunan dan pedoman hidup bagi manusia agar mencapai kebahagiaan dunia dan akhirat yang didalamnya mencakup kepercayaan kepada kekuatan ghaib yang selanjutnya menimbulkan respon emosional dan keyakinan bahwa kebahagiaan hidup tersebut tergantung pada adanya hubungan baik dengan kekuatan tersebut.

Nilai religius atau nilai agama adalah konsepsi yang tersurat maupun tersirat yang ada dalam agama yang mempengaruhi perilaku seseorang yang menganut agama tersebut yang mempunyai sifat hakiki dan datang dari Tuhan, juga kebenarannya diakui mutlak oleh penganut agama tersebut. Jadi dapat dipahami bahwa, nilai religius merupakan salah satu dari berbagai klasifikasi nilai di atas. Nilai religius bersumber dari agama dan mampu merasuk ke dalam intimitas jiwa. Nilai religius perlu ditanamkan dalam lembaga pendidikan untuk membentuk kepribadian muslim yang karimah dan kuat. Di samping itu, penanaman nilai religius ini penting dalam rangka untuk menjadikan etos kerja dan etos

\footnotetext{
${ }^{13}$ Nuruddin dkk, Agama Tradisional: Potret Kearifan Hidup Masyarakat Samin dan Tengger (Yogyakarta: LKIS, 2003), 126

${ }^{14}$ Roibin, Relasi Agama \& Budaya Masyarakat Kontemporer (Malang: UIN Maliki Press, 2009), 75

${ }^{15}$ Nursyam, Islam Pesisir (Yogyakarta: LKIS, 2005), 1
} 


\section{Agus Zainudin}

ilmiah seluruh sivitas akademika yang ada di lembaga pendidikan tersebut. Selain itu, juga supaya tertanam dalam diri tenaga kependidikan bahwa melakukan kegiatan pendidikan dan pembelajaran pada peserta didik bukan semata-mata bekerja untuk mencari uang, tetapi merupakan bagian dari pekerjaan ibadah.

\section{Konsep Akhlak Karimah}

\section{Pengertian Akhlak Karimah}

Akhlak memiliki dua pendekatan yang digunakan untuk mendefinisikan akhlak, yaitu pendekatan linguistik (bahasa), dan pendekatan terminologik (istilah). Dari sudut kebahasaan, akhlak berasal dari bahasa Arab, yaitu isim masdar (bentuk infinitif) dari kata akhlaqa, yukhliqu, ikhlaqan, sesuai dengan timbangan (wazan) tsulasi mazid af'ala, yuf'ilu, if'alan yang berarti al-sayijah (perangai), ath-thabiah (kelakuan, tabiat, watak dasar), al-'adat (kebiasaan, kelaziman), al-maru'ah (peradaban yang baik), dan al-din (agama). ${ }^{16}$

Namun kata akhlak dari akhlaqa sebagaimana tersebut di atas nampaknya kurang pas, sebab isim mashdar dari kata akhlaqa bukan akhlaq tetapi ikhlaq. Berkenaan dengan ini maka timbul pendapat yang mengatakan bahwa secara linguistik kata akhlaq merupakan isim jamid atau isim ghairu mustaq, yaitu isim yang tidak memiliki akar kata, melainkan kata tersebut sudah sedemikian adanya. Kata akhlaq adalah jamak dari kata khilqun atau khuluqun yang artinya sama dengan kata akhlaq. Sedangkan akhlak dalam bahasa Indonesia berasal dari kata khalaqa yang berarti mencipta, membuat dan menjadikan. Akhlaq selanjutnya dalam bahasa Indonesia disebut akhlak secara etimologi berarti perangai, adat, tabiat, atau system perilaku yang dibuat manusia. Akhlak secara kebahasaan bisa baik dan buruk tergantung pada tata nilai yang dipakai sebagai landasannya, meskipun secara sosisologis di Indonesia akhlak memiliki konotasai baik sehingga orang yang berakhlak berarti orang yang berakhlak baik. ${ }^{17}$

Sedangkan menurut aspek terminologi, akhlak dikemukakan oleh beberapa pakar, diantaranya:

\footnotetext{
${ }^{16}$ Abuddin Nata, Akhlak Tasawuf (Jakarta: Raja Grafindo Persada, 2000), 1

${ }^{17}$ Zainuddin Ali, Pendidikan Agama Islam (Jakarta: Bumi Aksara, 2010), 29
} 
Penanaman Nilai-Nilai Religius Dalam Membentuk

a. Ibnu Miskawaih, akhlak adalah keadaan jiwa seseorang yang mendorongnya untuk melakukan perbuatan-perbuatan tanpa melalui pertimbangan pikiran;

b. Imam Ghazali, akhlak adalah suatu sifat yang tertanam dalam jiwa yang dari padanya timbul perbuatan-perbuatan dengan mudah, dengan tidak memerlukan pertimbangan pemikiran;

c. Prof. Dr. Ahmad Amin, akhlak adalah kehendak yang dibiasakan yang artinya, kehendak itu bila membiasakan sesuatu, kebiasaan itu dinamakan akhlak. ${ }^{18}$

d. Ibrahim Anis, akhlak adalah sifat yang tertanam dalam jiwa yang melahirkan bermacam-macam perbuatan, baik atau buruk tanpa membutuhkan pemikiran dan pertimbangan. ${ }^{19}$

Dari beberapa pendapat diatas tentang akhlak dapat ditarik suatu kesimpulan bahwasanya akhlak merupakan sifat, perangai, tingkah laku baik atau buruk yang kemudian melahirkan berbagai macam perbuatan dan menjadi kebiasaan yang tidak membutuhkan pertimbangan dalam melakukannya.

Pengertian karimah menurut kamus besar bahasa Indonesia memiliki arti baik, dan terpuji. ${ }^{20}$ Kata karimah digunakan untuk menunjukkan pada perbuatan akhlak terpuji yang ditampakkan dalam kenyataan hidup sehari-hari. Selanjutnya kata alkarimah ini biasanya digunakan untuk menunjukkan perbuatan yang terpuji yang skalanya besar, seperti menafkahkan harta dijalan Allah, berbuat baik kepada kedua orang tua dan lain sebagainya. Akhlak mulia atau yang biasanya disebut dengan akhlak karimah menurut Al-Ghazali adalah keadaan batin yang baik. Di dalam batin manusia, yaitu dalam jiwanya terdapat empat tingkatan, dan dalam diri orang yang berakhlak baik, semua tingkatan itu tetap baik, moderat dan saling mengharmonisasikan. ${ }^{21}$

\section{Indikator Akhlak Karimah}

Untuk menciptakan peserta didik yang berakhlakul karimah, Islam memberikan tolak ukur jelas. Dalam menentukan perbuatan yang baik, Islam memperhatikan dari segi cara melakukan perbuatan tersebut. Seseorang yang berniat baik tapi

\footnotetext{
${ }^{18}$ Zahrudin AR dan Hasanudin Sinaga, Pengantar Studi Akhlak (Jakarta: PT. Raja Grafindo Persada, 2004), 4

${ }^{19}$ Amirulloh Syarbini dan Akhmad Khusaeri, Metode Islam dalam Membina Akhlak Remaja (Jakarta: PT. Alex Media Komputindo, 2012), 34

${ }^{20}$ Kemdikbud, "https://kbbi.kemdikbud.go.id/entri/karimah" (diakses pada Tanggal 01 April 2020 Pukul 14.09 WIB)

${ }^{21}$ M. Abul Quasem, Etika Al-Ghazali: Etika Majemuk di dalam Islam (Bandung: Pustaka, 1988), 82
} 


\section{Agus Zainudin}

melakukannya dengan menempuh cara yang salah maka perbuatan tersebut dipadang tercela. Indikator akhlakul karimah merupakan penuntun bagi umat manusia memiliki sifat dan mental serta kepribadian sebaik yang ditunjukan oleh al-quran dan hadist nabi Muhammad SAW. ${ }^{22}$ Selain itu, perbuatan dianggap baik dalam Islam adalah perbuatan yang sesuai dengan petunjuk al-quran dan perbuatan rasul-nya, yakni taat kepada allah dan rasul, menepati janji, menyayangi anak yatim, jujur, amanah, sabar, ridha, dan ikhlas. $^{23}$

Berdasarkan uraian di atas dapat disimpulkan bahwasannya dalam membina akhlakul karimah setiap lembaga pendidikan harus memiliki indikator akhlakul karimah yang akan dicapai oleh peserta didik. Beberapa indikator yang dapat diterapkan dilembaga pendidikan yang bersumber dari al-quran dan sunnah antara lain:

a. Amanah

Kata amanah diartikan sebagai jujur atau dapat dipercaya. Sedang dalam pengertian istilah, amanah adalah sesuatu yang dipercayakan kepada seseorang, baik harta atau ilmu atau rahasia lainnya yang wajib dipelihara dan disampaikan kepada yang berhak menerimanya. ${ }^{24}$ Amanah dalam Islam cukup luas pengertiannya, melambangkan arti yang bermacam-macam. Tapi semuanya bergantung kepada perasaan manusia yang dipercayakan amanat kepadanya. Oleh karena itu Islam mengajarkan agar memiliki hati kecil yang bisa melihat, menjaga, dan memelihara hak-hak Allah SWT. Maka Islam mewajibkan kepada umatnya untuk berlaku jujur dan dapat dipercaya.

b. Pemaaf

Pemaaf merupakan sikap suka memberi maaf terhadap kesalahan orang lain tanpa ada sedikitpun rasa benci dan keinginan untuk membalas. Sifat pemaaf adalah salah satu dari manifestasi ketaqwaan kepada Allah SWT. Islam mengajarkan kepada kita untuk dapat memaafkan kesalahan orang lain tanpa harus menunggu permohonan maaf dari yang bersalah. Jadi memaafkan itu berkaitan dengan menahan marah dan berbuat kebajikan. Tak ada yang lebih menenteramkan diri dan menenangkan padangan daripada hati yang jatuh serta jauh dari dengki.

${ }^{22}$ Sudarsono, Etika Islam Tentang Kenakalan Remaja (Jakarta: PT. Rineka Cipta, 2005), 151

${ }^{23}$ Ibid.

${ }^{24}$ Barmawi Umari, Materi Akhlak (Solo: Ramadhani, 1976), 44 
c. Sabar

Penanaman Nilai-Nilai Religius Dalam Membentuk........

Sabar secara bahasa berarti menahan. Secara syariat, sabar berarti menahan diri dari tiga hal: pertama, sabar untuk taat kepada Allah. Kedua, sabar dari hal-hal yang diharamkan Allah. Ketiga, sabar terhadap takdir Allah. ${ }^{25}$ Sabar bukan berarti menyerah tanpa syarat. Tetapi sabar adalah terus berusaha dengan hati yang tenang, berikhtiar, sampai cita-cita yang diinginkan berhasil dan dikala menerima cobaan dari Allah swt, wajiblah ridha dan dengan hati yang ikhlas.

d. Qana'ah

Menurut Hamka, qana'ah itu mengandung lima perkara yaitu:

1) Menerima dengan rela akan apa yang ada.

2) Memohon kepada Allah SWT tambahan yang pantas dan berusaha.

3) Menerima dengan sabar akan ketentuan Allah SWT.

4) Bertawakkal kepada Allah SWT.

5) Tidak tertarik oleh tipu daya dunia. ${ }^{26}$

Dengan kata lain, qana'ah berarti merasa cukup dan rela dengan pemberian yang dianugerahkan oleh Allah SWT. Maksud qana'ah itu amatlah luas. Menyuruh percaya dengan sebenar-benarnya akan adanya kekuasaan yang melebihi kekuasaan kita, menyuruh sabar menerima ketentuan Allah SWT jika ketentuan itu tidak menyenangkan diri dan bersyukur jika dipinjami-Nya nikmat, sebab kita tidak tahu kapan nikmat itu pergi. Dalam hal yang demikian kita disuruh bekerja, berusaha, bersungguh-sungguh, sebab semasa nyawa dikandunng badan, kewajiban belum berakhir. Kita bekerja bukan lantaran meminta tambahan yang telah ada dan tak merasa cukup pada apa yang ada di tangan, tetapi kita bekerja, sebab orang hidup mesti bekerja. ${ }^{27}$ Qana'ah tentunya sangat berpengaruh terhadap kehidupan pribadi maupun sosial. Terhadap kehidupan pribadi mampu meningkatkan wibawa, banyak disenangi sesama, mudah mendapat perlindungan dan tentunya mendapat ketenteraman dalam hati. Sedangkan terhadap kehidupan sosial mampu membina

\footnotetext{
${ }^{25}$ Syaikh Muhammad Al-Utsaimin, Syarah Riyadhus Shalihin, terj. Munirul Abidin (Jakarta: PT. Darul Falah, 2006), 113

${ }^{26}$ Zahrudin AR dan Hasanuddin Sinaga, Pengantar Studi Akhlak (Jakarta: PT. Raja Grafindo Persada, 2004), 160

${ }^{27}$ Hamka, Tasawuf Modern (Jakarta: Pustaka Panjimas, 1990), 230
} 


\section{Agus Zainudin}

dan menjaga kerukunan tetangga yang terwujud dalam sikap saling menghormati, saling melindungi, saling menjaga, dan saling peduli satu dengan lainnya sehingga akan tercipta masyarakat yang aman, tenang, tentram dan sejahtera.

e. Kebersihan (An-Nadzafah)

Kebersihan adalah upaya manusia untuk memelihara diri dan lingkungannya dari segala hal yang kotor dan keji dalam rangka mewujudkan dan melestarikan kehidupan yang sehat dan nyaman. Kebersihan merupakan syarat bagi terwujudnya kesehatan dan sehat adalah salah satu faktor yang dapat memberikan kebahagiaan. Sebaliknya, kotor tidak saja merusak keindahan tetapi juga dapat menyebabkan timbulnya berbagai penyakit, dan sakit merupakan salah satu faktor yang dapat menimbulkan penderitaa. Dan sesungguhnya Allah menyukai kaum yang suka membersihkan diri.

\section{Macam-Macam Akhlak Karimah}

Akhlak Islami ialah akhlak yang berdasarkan ajaran Islam atau akhlak yang bersifat Islami. Kedudukan akhlak dalam kehidupan manusia menempati tempat yang penting secara individu maupun anggota masyarakat. Dalam pembahasan akhlak Islami tidak hanya membahas akhlak sesama manusia, tetapi juga membahas akhlak kepada khalik (Allah SWT), lingkungan (alam semesta). ${ }^{28}$ Dari penjelasan ini dapat disimpulkan bahwa macam-macam akhlakul karimah ini dibagi menjadi 3, yaitu:

a. Akhlak manusia sebagai hamba Allah (Akhlak kepada Allah)

Alam ini mempunyai pencipta dan pemelihara yang diyakini ada-Nya, yakni Allah SWT. Dia lah yang memberikan rahmat dan menurunkan adzab kepada siapa yang dikehendaki-Nya. Dialah yang wajib diibadahi dan ditaati oleh segenap manusia. ${ }^{29}$ Oleh karena itu manusia berhutang budi yang besar, karena berkat Rahman dan Rahim-Nya Dia telah menganugerahkan nikmat yang tak terhitung jumlahnya. Sebagai makhluk ciptaan Allah SWT, manusia diberikan oleh Allah SWT kesempurnaan dalam penciptaan-Nya yang mempunyai kelebihan daripada makhuk ciptaan-Nya yang lain yaitu diberikan akal untuk berpikir, perasaan dan

\footnotetext{
${ }^{28}$ Yatimin Abdullah, Studi Akhlak dalam Perspektif Al-Qur'an (Jakarta: AMZAH, 2007), 197

${ }^{29}$ Hamzah Ya’qub, Etika Islam (Pembinaan Akhlakul Karimah) (Bandung: CV. Diponegoro, 1983), 140141
}

28 | Jurnal Auladuna 
Penanaman Nilai-Nilai Religius Dalam Membentuk

nafsu. ${ }^{30}$ Akhlak kepada Allah SWT dapat diartikan sebagai sikap atau perbuatan yang seharusnya dilakukan oleh manusia sebagai makhuk Allah SWT. Berkenaan dengan akhlak kepada Allah dilaksanakan dengan cara memuji-Nya, yakni menjadikan Tuhan sebagai satu-satunya yang menguasai dirinya. Oleh sebab itu, manusia sebagai hamba Allah SWT mempuyai cara-cara yang tepat untuk menekatkan diri Caranya adalah sebagai berikut:

1) Mentauhidkan Allah

Mentauhidkan Allah SWT berarti bahwa seseorang itu harus meyakini bahwa tidak ada Tuhan selain Allah, hal ini berarti seorang manusia hanya boleh bergantung kepada Allah SWT. ${ }^{31}$

2) Beribadah kepada Allah SWT

Orang yang beriman kepada Allah SWT akan senantiasa melakukan berbagai ibadah seperti shalat, puasa, zakat, haji dan lain-lain. Ibadah tersebut dilaksanakan untuk mendekatkan diri kepada Allah SWT.

3) Bertakwa kepada Allah SWT

Adapun yang dimaksud dengan bertakwa kepada Allah SWT adalah melaksanakan apa-apa yang diperintahkan Allah dan meninggalkan apa-apa yang dilarang-Nya. ${ }^{32}$ Takwa ini dapat dilakukan dimana saja berada, di tempat ramai atau di tempat yang sepi, sendirian atau tidak ada orang lain, disaat senang atau dikala susah.

4) Berdoa khusus kepada Allah SWT

Berdoa berarti meminta sesuatu kepada Tuhan,yakni meminta Allah SWT supaya hajat dan kehendak makhluk-Nya dikabulkan. Allah SWT berfirman melalui alquran agar manusia berdoa kepada- Nya, sebab Dia Maha Dekat, sedekat urat leher. Allah mendengar pinta hamba-Nya, pinta yang baik. Allah SWT tidak penah menyalahi janji-Nya. ${ }^{33}$ Oleh karena itu kita harus bersungguhsungguh dalam memohon doa dan dengan bertawakal. Selain itu, kita juga harus berdoa dengan hati yang yakin dan mantap. Bertawakal adalah berusaha dengan

${ }^{30}$ Yatimin Abdullah, Studi Akhlak dalam Perspektif Al-Qur'an (Jakarta: Amzah, 2007), 197

${ }^{31} \mathrm{Ibid}$.

${ }^{32}$ Ibid., 202

${ }^{33}$ Ibid., 203 


\section{Agus Zainudin}

berdoa dan bertindak. Bila ada orang yang menganggap dirinya bertawakal karena selalu berdoa kepada Tuhan, tetapi ia tidak mau bekerja mencari apa yang telah diminta dalam doanya, maka hal itu tidak dapat disebut sebagai tawakal. ${ }^{34}$ Oleh karena itu kita harus senatiasa berusaha dan berdoa agar apa yang kita harapkan dapat terwujud.

5) Zikrulloh

Zikir yaitu banyak ingat kepada Allah SWT, memperbanyak mengingat Allah, baik di waktu lapang maupun di waktu sempit, baik di waktu sehat maupun di waktu sakit. ${ }^{35}$ Kita sebagai hamba Allah SWT, harus senantiasa memperbanyak zikir karena dengan berzikir kita akan senantiasa selalu mengingat Allah dan dekat dengan Allah.

6) Bertawakal

Tawakal maksudnya ialah berserah diri kepada Allah dan menerima apa saja yang telah ditentukannya, tetapi dengan cara berusaha (ikhtiar) sekuat tenaga disertai dengan doa. ${ }^{36}$ Karena doa yang kita panjatkan harus diiringi dengan usaha. Bertawakal adalah berusaha dengan berdoa dan bertindak. Bila ada orang yang menganggap dirinya bertawakal karena selalu berdoa kepada Tuhan, tetapi ia tidak mau bekerja mencari apa yang telah diminta dalam doanya, maka hal itu tidak dapat disebut sebagai tawakal. Oleh karena itu kita harus senatiasa berusaha dan berdoa agar apa yang kita harapkan dapat terwujud.

7) Bersabar

Sabar artinya tahan menderita dari hal-al yang negatif atau karena hal-hal yang positif. Ali bin Abi Thalib berkata, "sabar itu ada dua, sabar atas apa-apa yang tidak engkau sukai dan sabar atas apa-apa yang kau sukai". ${ }^{37}$ Sabar juga dapat diartikan menahan diri dari hawa nafsu yang selalu ingin bersenang-senang. Sabar dibagi menjadi tiga bagian yaitu:

a) Sabar meninggalkan larangan agama;

b) Sabar mejalankan perintah agama;

${ }^{34}$ Mahjuddin, Membina Akhlak Anak (Surabaya: Al Ikhlas, 1995), 34

${ }^{35}$ Yatimin Abdullah, Studi Akhlak dalam Perspektif Al-Qur'an (Jakarta: Amzah, 2007), 204

${ }^{36} \mathrm{Ibid}$.

${ }^{37} \mathrm{Ibid}, .206$ 
Penanaman Nilai-Nilai Religius Dalam Membentuk........ c) Sabar menerima ujian dan cobaan dari Allah SWT.

8) Bersyukur kepada Allah

Syukur ialah suatu sifat mulia yang wajib dimiliki oleh setiap individu muslim, yaitu menyadari bahwa segala nikmat yang ada pada dirinya itu merupakan karunia dan anugerah dari Allah semata dan menggunakan nikmatnikmat itu sesuai dengan ketentuan yang telah ditetapkan oleh-Nya. Syukur berarti meggunakan segala nikmat karunia Allah SWT menurut batas-batas yang telah ditetapkan. Selain itu menjaga dan memeliharanya dari penyelewengan atau melakukan larangan yang telah diharamkan- Nya.

b. Akhlak terhadap sesama manusia

Islam memerintahkan pemeluknya untuk menunaikan hak-hak pribadinya dan berlaku adil terhadap dirinya. Islam dalam pemenuhan hak-hak pribadinya tidak boleh merugikan orang lain. ${ }^{38}$ Hal ini menunjukkan bahwa Islam memgimbangi hak-hak pribadi dan hak orang lain supaya tidak timbul pertentangan. Sebagai seorang muslim harus menjaga perasaan orang lain, tidak boleh membedakan sikap terhadap seseorang.

Akhlak terhadap sesama manusia merupakan sikap seseorang terhadap orang lain. Sikap-sikap yang harus dikembangkan, antara lain:

1) Menghormati perasaan orang lain dengan cara yang baik seperti yang disyariatkan agama, jangan tertawa di depan orang yang bersedih, jangan mencaci sesama manusia, jangan menfitnah dan menggunjing, jangan melaknat manusia dan jangan makan di depan orang yang berpuasa.

2) Memberi salam dan menjawab salam dengan memperlihatkan muka manis, mencintai saudara sesama muslim sebagaimana mencintai dirinya sendiri, dan menyenangi kebaikan.

3) Pandai berterima kasih. Manusia yang baik adalah manusia yang pandai berterima kasih.

4) Memenuhi janji, karena janji adalah amanah yang harus dipenuhi.

5) Tidak boleh mengejek atau merendahkan orang lain.

${ }^{38}$ Ibid., 212 


\section{Agus Zainudin}

6) Jangan mencari-cari kesalahan. Orang yang sering mencari-cari kesalahan orang lain adalah orang yang berakhlaqul madzmunah.

7) Jangan menawar sesuatu yang sedang ditawar orag lain dalam berbelanja.

c. Akhlak terhadap alam

Alam ialah segala sesuatu yang ada di langit dan bumi beserta isinya, selain Allah SWT, manusia sebagai khalifah diberi kemampuan oleh Allah untuk mengelola alam semesta ini. Manusia sebagai khalifah diberi kemampuan oleh Allah untuk mengelola alam semesta ini. ${ }^{36}$ Hal ini menunjukkan manusia diturunkan ke bumi membawa rahmat dan cinta kasih kepada alam seisinya. Akhlak terhadap alam, antara lain sebagai berikut:

1) Bahwa manusia itu hidup dan mati di alam, yaitu bumi.

2) Bahwa alam merupakan salah satu yang dibicarakan oleh alquran.

3) Bahwa Allah memerintahkan manusia untuk menjaga pelestarian alam, agar kehidupannya menjadi makmur.

4) Bahwa Allah memerintahkan kepada manusia untuk mengambil manfaat yang sebesar-besarnya dari alam agar kehidupannya menjadi makmur.

5) Manusia berkewajiban mewujudkan kemakmuran dan kebahagiaan di muka bumi. $^{39}$

\section{Penanaman Nilai-Nilai Religius dalam Membentuk Akhlak Karimah bagi Peserta Didik di MI Ar-Rahim Kecamatan Arjasa Kabupaten Jember}

Dalam pengertian yang lebih praktis dan bersifat aplikatif, pendidikan Islam setidaknya memiliki dua substansi, yakni: pertama, pendidikan Islam adalah aktivitas pendidikan yang didirikan atau diselenggarakan dengan niat dan tujuan untuk mengejawantahkan ajaran dan nilai-nilai Islam. Kedua, pendidikan Islam adalah sistem pendidikan yang dikembangkan dari dan dijiwai oleh ajaran serta nilai-nilai Islam. ${ }^{40}$

\footnotetext{
39 Ibid., 230-231

${ }^{40}$ Poin pertama dalam prakteknya di Indonesia terdiri atas beberapa jenis, di antaranya adalah: (1) pondok pesantren atau madrasah diniyah; (2) PAUD/ RA, BA, TA, madrasah dan Perguruan Tinggi Islam yang bernaung di bawah Kementerian Agama; (3) PAUD/ RA, BA, TA, madrasah dan perguruan tinggi yang berada di bawah naungan yayasan atau organisasi Islam; (4) pelajaran agama Islam di sekolah/ madrasah/ perguruan tinggi; dan (5) pendidikan Islam dalam keluarga atau di tempat-tempat ibadah serta forum-forum kajian atau majelis ke-Islaman. Poin kedua di antaranya mencakup: (1) pendidik/ guru/ dosen, kepala madrasah/ sekolah atau pimpinan perguruan tinggi dan/ atau tenaga kependidikan lainnya yang melakukan
} 
Penanaman Nilai-Nilai Religius Dalam Membentuk........ Untuk itu, unsur apapun yang akan diintegrasikan atau dikembangkan dalam setiap dimensi pendidikan Islam, harus diarahkan pada konsep dan bentuk-bentuk pendidikan Islam, baik yang bersifat normatif maupun praktis (sistem dan aktivitas).

Kegiatan-kegiatan yang dapat membentuk kepribadian muslim di lingkungan lembaga pendidikan antara lain pertama, melakukan kegiatan rutin, yaitu penanaman nilai-nilai religius secara rutin berlangsung pada hari-hari belajar biasa di lembaga pendidikan. Kegiatan rutin ini dilakukan dalam kegiatan sehari-hari yang terintegrasi dengan kegiatan yang telah diprogramkan, sehingga tidak memerlukan waktu khusus. Pendidikan agama merupakan tugas dan tanggung jawab bersama bukan hanya guru agama saja melainkan juga tugas dan tanggung jawab guru-guru bidang studi lainnya atau sekolah. Pendidikan agama pun tidak hanya terbatas pada aspek pengetahuan, tetapi juga meliputi pembentukan sikap, perilaku, dan pengalaman keagamaan. Untuk itu pembentukan sikap, perilaku, dan pengalaman keagamaan pun tidak hanya dilakukan oleh guru agama, tetapi perlu didukung oleh guru-guru bidang studi lainnya.

Kedua, menciptakan lingkungan lembaga pendidikan yang mendukung dan menjadi laboratorium bagi penyampaian pendidikan agama, sehingga lingkungan dan proses kehidupan semacam ini bagi para peserta didik benar-benar bisa memberikan pendidikan tentang caranya belajar beragama. Dalam proses tumbuh kembangnya peserta didik dipengaruhi oleh lingkungan lembaga pendidikan, selain lingkungan keluarga dan lingkungan masyarakat. Suasana lingkungan lembaga pendidikan dapat menumbuhkan budaya keagamaan. Lembaga pendidikan mampu menanamkan sosialisasi dan nilai yang dapat menciptakan generasi-generasi yang berkualitas dan berkarakter kuat, sehingga menjadi pelaku-pelaku utama kehidupan di masyarakat. Suasana lingkungan lembaga ini dapat membimbing peserta didik agar mempunyai akhlak karimah, perilaku jujur, disiplin dan semangat sehingga akhirnya menjadi dasar untuk meningkatkan kualitas dirinya.

dan mengembangkan aktivitas kependidikan dengan dilandasi semangat ajaran dan nilai-nilai Islam; (2) komponen-komponen pendidikan lainnya, seperti tujuan, materi/ bahan ajar, alat/ media/ sumber belajar, metode, evaluasi, lingkungan/ konteks, manajemen, dan lain-lain yang didasari nilai-nilai Islam. Lihat Muhaimin, et. al., Manajemen Pendidikan: Aplikasi dalam Penyusunan Rencana Pengembangan Sekolah Madrasah (Jakarta: Kencana, 2009), 3-4 


\section{Agus Zainudin}

Ketiga, pendidikan agama tidak hanya disampaikan secara formal oleh guru agama dengan materi pelajaran agama dalam suatu proses pembelajaran, namun dapat pula dilakukan di luar proses pembelajaran dalam kehidupan sehari-hari. Guru bisa memberikan pendidikan agama secara spontan ketika menghadapi sikap atau perilaku peserta didik yang tidak sesuai dengan ajaran agama. Manfaat pendidikan secara spontan ini menjadikan peserta didik langsung mengetahui dan menyadari kesalahan yang dilakukannya dan langsung pula mampu memperbaikinya. Manfaat lainnya dapat dijadikan pelajaran atau hikmah oleh peserta didik lainnya, jika perbuatan salah jangan ditiru, sebaliknya jika ada perbuatan yang baik harus ditiru.

Keempat, menciptakan situasi atau keadaan religius. Tujuannya untuk mengenalkan kepada peserta didik tentang pengertian agama dan tata cara pelaksanaan agama tersebut dalam kehidupan sehari-hari. Selain itu juga menunjukkan pengembangan kehidupan religius di lembaga pendidikan yang tergambar dari perilaku sehari-hari dari berbagai kegiatan yang dilakukan oleh guru dan peserta didik. Oleh karena itu keadaan atau situasi keagamaan di sekolah yang dapat diciptakan antara lain pengadaan peralatan peribadatan seperti tempat untuk shalat (masjid atau mushalla), alat-alat shalat seperti sarung, peci, mukena, sajadah atau pengadaan al-Quran. Selain itu di ruangan kelas bisa pula ditempelkan kaligrafi, sehingga peserta didik dibiasakan selalu melihat sesuatu yang baik. Selain itu dengan menciptakan suasana kehidupan keagamaan di sekolah antara sesama guru, guru dengan peserta didik, atau antar peserta didik. Misalnya, dengan mengucapkan kata-kata yang baik ketika bertemu atau berpisah, mengawali dan mengakhiri suatu kegiatan, mengajukan pendapatan atau pertanyaan dengan cara yang baik, sopan, santun tidak merendahkan peserta didik lainnya, dan sebagainya.

Kelima, memberikan kesempatan kepada peserta didik sekolah/ madrasah untuk mengekspresikan diri, menumbuhkan bakat, minat dan kreativitas pendidikan agama dalam keterampilan dan seni, seperti membaca al-Quran, adzan, sari tilawah, serta untuk mendorong peserta didik sekolah mencintai kitab suci, dan meningkatkan minat peserta didik untuk membaca, menulis serta mempelajari isi kandungan al-Quran. Dalam membahas suatu materi pelajaran agar lebih jelas guru hendaknya selalu diperkuat oleh nas-nas keagamaan yang sesuai berlandaskan pada al-Quran dan Hadits 
Penanaman Nilai-Nilai Religius Dalam Membentuk Rasulullah saw. Tidak hanya ketika mengajar saja tetapi dalam setiap kesempatan guru harus mengembangkan kesadaran beragama dan menanamkan jiwa keberagamaan yang benar. Guru memperhatikan minat keberagaman peserta didik. Untuk itu guru harus mampu menciptakan dan memanfaatkan suasana keberagamaan dengan menciptakan suasana dalam peribadatan seperti shalat, puasa dan lain-lain.

Keenam, menyelenggarakan berbagai macam perlombaan seperti cerdas cermat untuk melatih dan membiasakan keberanian, kecepatan, dan ketepatan menyampaikan pengetahuan dan mempraktikkan materi pendidikan agama Islam. Mengadakan perlombaan adalah sesuatu yang sangat menyenangkan bagi peserta didik, membantu peserta didik dalam melakukan kegiatan-kegiatan yang bermanfaat, menambah wawasan dan membantu mengembangkan kecerdasan serta menambahkan rasa kecintaan. Perlombaan bermanfaat sangat besar bagi peserta didik berupa pendalaman pelajaran yang akan membantu mereka untuk mendapatkan hasil belajar secara maksimal. Perlombaan dapat membantu para pendidik dalam mengisi waktu kekosongan waktu peserta didik dengan sesuatu yang bermanfaat bagi mereka dan pekelahian pelajar dapat dihindarkan. Dari perlombaan ini memberikan kreativitas kepada peserta didik dengan menanamkan rasa percaya diri pada mereka agar mempermudah bagi peserta didik untuk memberikan pengarahan yang dapat mengembangkan kreativitasnya. Nilai-nilai yang terkandung dalam perlombaan itu antara lain adanya nilai pendidikan di mana peserta didik mendapatkan pengetahuan, nilai sosial, yaitu peserta didik bersosialisasi atau bergaul dengan yang lainnya, nilai akhlak yaitu dapat membedakan yang benar dan yang salah, seperti adil, jujur, amanah, jiwa sportif, mandiri. Selain itu ada nilai kreativitas dapat mengekspresikan kemampuan kreativitasnya dengan cara mencoba sesuatu yang ada dalam pikirannya.

Dalam aspek praktik keseharian, nilai-nilai religius yang telah disepakati tersebut diwujudkan dalam bentuk sikap dan perilaku keseharian oleh semua warga sekolah. Proses pengembangan tersebut dapat dilakukan melalui tiga tahap, yaitu: pertama, sosialisasi nilai-nilai religius yang disepakati sebagai sikap dan perilaku ideal yang ingin dicapai pada masa mendatang di lembaga pendidikan. Kedua, penetapan action plan mingguan atau bulanan sebagai tahapan dan langkah sistematis yang akan dilakukan oleh semua pihak di lembaga pendidikan yang mewujudkan nilai-nilai 


\section{Agus Zainudin}

religius yang telah disepakati tersebut. Ketiga, pemberian penghargaan terhadap prestasi warga lembaga pendidikan, seperti guru, tenaga kependidikan, dan peserta didik sebagai usaha pembiasaan (habit formation) yang menjunjung sikap dan perilaku yang komitmen dan loyal terhadap ajaran dan nilai-nilai religius yang disepakati. Penghargaan tidak selalu berarti materi (ekonomik), melainkan juga dalam arti sosial, kultural, psikologis ataupun lainnya. ${ }^{41}$

Dalam aspek simbol-simbol budaya, pengembangan yang perlu dilakukan adalah mengganti simbol-simbol budaya yang kurang sejalan dengan ajaran dan nilainilai agama dengan simbol budaya yang agamis. Perubahan simbol dapat dilakukan dengan mengubah model berpakaian dengan prinsip menutup aurat, pemasangan hasil karya peserta didik, foto-foto dan motto yang mengandung pesan-pesan nilai keagamaan. ${ }^{42}$

Budaya religius digunakan sebagai wahana penanaman nilai-nilai religius. Hal tersebut dikarenakan penanaman nilai-nilai religius merupakan awal mula dari budaya religius. Budaya religius dibentuk salah satunya dengan pendidikan nilai religius yang dilakukan secara kontinyu dan terus-menerus oleh suatu lembaga pendidikan, maka akan semua civitas akademika yang ada di lembaga tersebut akan melakukan nilai-nilai religius dan membiasakan dalam kehidupan sehari-hari. Namun, untuk mewujudkan menjadi budaya, maka perlu diterapkan budaya religius yang toleran dan mengajarkan keuniversalitasan nilai religius tersebut sehingga peserta didik diharapkan mempunyai akhlak karimah.

Penanaman nilai religius mempunyai posisi yang penting dalam upaya membentuk akhlak karimah pada peserta didik. Karena hanya dengan penanaman nilai religius, peserta didik akan menyadari pentingnya nilai religius secara kontinyu dalam kehidupan sehari-hari. Jadi, dalam penanaman nilai-nilai religius tersebut memberikan pemahaman dan kesadaran bahwa nilai-nilai agama tidak hanya dihafal atau hanya berhenti pada wilayah kognisi, akan tetapi juga harus sampai menyentuh aspek afeksi dan psikomotorik bahkan menyentuh aspek saling menghormati antar sesama.

${ }^{41}$ Muhaimin, Rekonstruksi Pendidikan Islam: dari Paradigma Pengembangan, Manajemen Kelembagaan, Kurikulum hingga Strategi Pembelajaran (Jakarta: Raja Grafindo Persada, 2009), 326

${ }^{42}$ Asmaun Sahlan, Mewujudkan Budaya Religius di Sekolah: Upaya Mengembangkan PAI dari Teori ke Aksi, (Malang: UIN Maliki Press, 2010), 86 


\section{PENUTUP}

Penanaman Nilai-Nilai Religius Dalam Membentuk........

\section{Simpulan}

Nilai-nilai religius merupakan nilai sangat penting untuk ditanamkan kepada peserta didik. Nilai tersebut akan mampu menjadikan peserta didik menjadi lebih toleran dan lebih religius bahkan mengamalkan ajaran agamanya dan menyentuh afeksi dan psikomotoriknya. Penanaman nilai religius dilakukan dengan membentuk budaya religius sehingga pada akhirnya peserta didik akan terbiasa mengamalkan nilai-nilai religius dan akan menjadi peserta didik yang menghormati sesamanya bahkan dengan yang lain agama dengan akhlak karimah.

\section{DAFTAR PUSTAKA}

Abdullah, Yatimin. Studi Akhlak dalam Perspektif Al-Qur'an. Jakarta: Amzah, 2007.

Ali, Zainuddin. Pendidikan Agama Islam. Jakarta: Bumi Aksara, 2010.

AR, Zahrudin dan Hasanudin Sinaga. Pengantar Studi Akhlak. Jakarta: PT. Raja Grafindo Persada, 2004.

Al-Utsaimin, Muhammad. Syarah Riyadhus Shalihin, terj. Munirul Abidin. Jakarta: PT. Darul Falah, 2006.

Badudu, JS dan Sutan Muhammad Zain. Kamus Umum Bahasa Indonesia. Jakarta: Pustaka Sinar Harapan, 1996.

Fathiya, Kartika Nur. Problem Dampak dan Solusi Transformasi Nilai-nilai Agama pada Anak Pra-sekolah. Dinamika Pendidikan No. 1/ Th. XIV/ Mei, 2007.

Hamka. Tasawuf Modern. Jakarta: Pustaka Panjimas, 1990.

Haris, Abd. Etika Hamka. Yogyakarta: LkiS, 2012.

Kemdikbud. https://kbbi.kemdikbud.go.id/entri/nilai (diakses pada Tanggal 01 April 2020 Pukul 14.09 WIB)

. https://kbbi.kemdikbud.go.id/entri/nilai (diakses pada Tanggal 01 April 2020 Pukul 13.26 WIB)

Mahjuddin. Membina Akhlak Anak. Surabaya: Al Ikhlas, 1995.

Marzuki. Pendidikan Agama Islam di Perguruan Tinggi Umum dan Pemberdayaan Masyarakat Indonesia. Cakrawala Pendidikan No. 1 Tahun XVI Februari, 1997. 
Agus Zainudin

Muhaimin. Rekonstruksi Pendidikan Islam: dari Paradigma Pengembangan, Manajemen Kelembagaan, Kurikulum hingga Strategi Pembelajaran. Jakarta: Raja Grafindo Persada, 2009.

Muhaimin, et. al. Manajemen Pendidikan: Aplikasi dalam Penyusunan Rencana Pengembangan Sekolah/ Madrasah. Jakarta: Kencana, 2009.

Muhmidayeli. Filsafat Pendidikan. Bandung: Refika Aditama, 2013.

Mulyana, Rohmat. Mengartikulasikan Pendidikan Nilai. Bandung: Alfabeta, 2004.

Nata, Abuddin. Metodologi Studi Islam. Jakarta: Raja Grafindo Persada 2003. . Akhlak Tasawuf. Jakarta: Raja Grafindo Persada, 2000.

Nursyam. Islam Pesisir. Yogyakarta: LKIS, 2005.

Nuruddin, dkk. Agama Tradisional: Potret Kearifan Hidup Masyarakat Samin dan Tengger. Yogyakarta: LKIS, 2003.

Quasem , M. Abul. Etika Al-Ghazali: Etika Majemuk di dalam Islam. Bandung: Pustaka, 1988.

Roibin. Relasi Agama \& Budaya Masyarakat Kontemporer. Malang: UIN Maliki Press, 2009.

Rosyadi, Khoiron. Pendidikan Profetik, cet. 1. Yogyakarta: Pustaka Pelajar, 2004.

Sahlan, Asmaun. Mewujudkan Budaya Religius di Sekolah: Upaya Mengembangkan PAI dari Teori ke Aksi. Malang: UIN Maliki Press, 2010.

Sudarsono. Etika Islam Tentang Kenakalan Remaja. Jakarta: PT. Rineka Cipta, 2005.

Sulistiyorini. Manajemen Pendidikan Islam. Surabaya: eLKAF, 2006.

Syarbini, Amirulloh dan Akhmad Khusaeri. Metode Islam dalam Membina Akhlak Remaja. Jakarta: PT. Alex Media Komputindo, 2012.

Tafsir, Ahmad. Ilmu Pendidikan dalam Perspektif Islam. Bandung: Remaja Rosda Karya, 1992.

Umari, Barmawi. Materi Akhlak. Solo: Ramadhani, 1976.

Ya’qub, Hamzah. Etika Islam (Pembinaan Akhlakul Karimah). Bandung: CV. Diponegoro, 1983. 